\title{
Konflik Etnisitas di Aceh Masa Reformasi, 1998-2005
}

\author{
Imam H. Sutrisno
}

\begin{abstract}
Program Studi Pendidikan Sejarah, Fakultas Ilmu Keguruan dan Pendidikan, Universitas Langsa
\end{abstract}

Corresponding Author: imamhadisutrisno@yahoo.co.id

\begin{abstract}
Sejarah Aceh selalu lekat dengan konflik dengan latar politik baik pada masa kolonial maupun Indonesia kontemporer seperti Perang Aceh, Darul Islam/Tentara Islam Indonesia (DI/TII), dan Gerakan Aceh Merdeka (GAM), tetapi tulisan ini lebih memfokuskan pada konflik dengan latar etnisitas yang muncul

Received:

27 Juni 2018

Accepted:

2 July 2018 pada masa reformasi 1998-2005. Dengan metode sejarah kritis dapat diketahui, bahwa konflik etnisitas di Aceh masa reformasi itu lebih dipengaruhi oleh euphoria reformasi dan menguatnya semangat otonomi daerah yang direpresentasi sebagai 'kekuasaan' yang harus ditangan orang daerah-etnik local dan merupakan konflik harisontal sesama warga bangsa dengan latar etnik yang berbeda. Dalam konflik horisontal ini yang cukup menonjol terjadi antara etnik lokal dengan etnik pendatang terutama etnik Jawa yang dianggap telah menguasai etnik local terutama secara ekonomi dan sosiokultural. Sebagai etnik pendatang, orang-orang Jawa di Aceh secara ekonomi lebih maju dibandingkan penduduk local yang notabene berasal dari etnik setempat. Selain itu, secara sosiokultural orang Jawa di Aceh juga menempati posisi social yang penting dan lebih baik dibandingkan dengan penduduk Aceh. Konflik dengan latar etnik di Aceh tentu berbeda dengan konflik dengan latar dan tujuan politik seperti Tengku Daud Beureureh yang memimpin DI/TII, Tengku Hasan Tiro yang memimpin Gerakan Aceh Merdeka/GAM.
\end{abstract}

Kata Kunci: Etnisitas; Konflik Aceh; Reformasi

\section{Pendahuluan}

Melacak jejak sejarahnya, sejak kasultanan Iskandar Muda Aceh telah mampu memberikan peluang bagi pedagang asing untuk melaksanakan aktivitas ekonomi bahkan hingga diberikan izin untuk tinggal tetap sementara. Oleh karena itu, dalam 
tata kota kerajaan Aceh sudah ter-mapping-kan bahwa daerah seperti Kampong Kedah itu merupakan wilayah pemukiman orang asing yang menetap sementara di sekitar istana. Demikian juga kehadiran pedagang etnik Jawa, mereka diberikan tempat sesuai dengan nama asal etnik yakni dikenal dengan nama Kampong Jawa yang hingga sekarang masih bisa terlihat di wilayah Banda Aceh.

Sejalan dengan dinamika ekonomi di Aceh tersebut, Aceh juga sarat dengan konflik sebagaimana yang dikemukakan Reid (2007) bahwa Aceh sarat dengan konflik dan konflik itu terjadi setelah mangkatnya Sultan Iskandar Muda terjadi perebutan kekuasaan. Dalam perkembangannya kemudian pada masa transisi seperti saat ini, dengan adanya kebijakan pemerintah yang mengarah pada desentralisasi, isu etnisitas mencuat yang berpotensi terjadinya konflik sosial berbasis agama dan etnis (Haryanto, 2012: 302). Pelaksanaan otonomi daerah ditengarai justru menguatkan identitas primordial (khususnya etnis). Dalam konteks perebutan kekuasaan tersebut, konflik selalu terjadi dari generasi ke generasi hingga masa Aceh kontemporer yang mengusung isu Aceh Merdeka melalui GAM (Reid, 2004: 309). Sejarah konflik di Aceh memang lebih didominasi berlatar politik. Namun demikian fakta terkini justru muncul konflik yang berlatar etniksitas yang terjadi masa reformasi.

Etsinitas adalah perubahan kata dari kata etnik yang berarti kesukuan atau kelompok kesukuan (ethnic group). Ada banyak kebingungan dengan istilah-istilah khusus seperti 'kelompok etnis', 'kelompok rasial', 'kasta' dan 'stratum sosial' (Burger, et.al., 1990: 42). Secara umum sosiologi menolak gagasan bahwa kelompok manusia dapat didefinisikan dalam pengertian genetic mereka. Kelompok sosial dalam teori sosiologi didefinisikan secara lebih umum dengan mengacu pada kesamaan budaya seperti bahasa, adat dan lembaga. Ada perbedaan kelompok yang karakternya dipaksakan atasnya oleh kelompok politik yang superior dalam konteks pertarungan politik. Oleh karena itu, etnisitas mungkin menjadi landasan baik untuk separatism nasional atau subordinasi politik. Ambiguitas 'kelompok etnis' dengan demikian mencerminkan pertarungan politik untuk keanggotaan kelompok ekskutif dan inklusif (Aberrcrombie, 2010: 191).

Menurut Eriksen (1993), etnisitas berasal dari bahasa Yunani, ethnos (ethnikos) yang berarti tidak beragama. Ethnic digunakan oleh orang-orang Eropa untuk menyebutkan suku aborigin barat sebagai masyarakat yang belum beradab dan beragama (Eriksen, 1993: 10). Namun pernyataan sosiolog dan antropolog mempunyai sudut pandang yang berbeda, perbedaan tersebut terdapat pada pengkatagorian fungsi, ciri, dan syarat kemunculan etnisitas. Kajian aspek sosial politik tentang etnik disebut dengan etnisitas. Dalam pandangan Herowitz (1985) bahwa hal tersebut bisa dilihat dari faktor darah dan kelahiran, di mana berdasarkan faktor tersebut seorang dapat dibedakan atas dasar warna kulit, bahasa dan kepercayaan (Herowitz, 1985: 52-53). Sementara Manger (1994) dalam identitas kelompok etnik mempunyai dua pandangan, yaitu (1) sebagai sebuah unit yang obyektif yang dapat diartikan oleh perbedaan budaya seseorang, atau (2) hanya sekedar produk pemikiran sebagai suatu kelompok etnik (Manger, 1994: 13). 
Dalam kajian antropologi, Barth menyebutkan bahwa umumnya kelompok etnik sebagai suatu komunitas memiliki kharateristik sebagai berikut: (1) secara biologis mampu berkembang biak dan bertahan, (2) mempunyai nilai-nilai budaya yang sama dan sadar akan kebersamaan dalam satu bentuk budaya, (3) membentuk jaringan komunikasi dan interaksi sendiri, dan (4) menentukan ciri kelompoknya sendiri yang diterima oleh kelompok lain dan dapat dibedakan dari kelompok komunitas yang lain (Barth, 1988: 11).

Berdasarkan uraian tersebut, maka penulis dapat memberikan makna atas etnisitas. Makna tersebut dapat ditelusuri dari dua hal. Pertama, etnisitas adalah rangkaian penanda dalam hubungan sosial. Kedua, etnisitas merupakan sumber politik identitas. Oleh karena itu, tulisan ini membahas beberapa permasalahan lebih lanjut, yaitu bagaimana isu etnisitas mewarnai konflik harisontal di Aceh masa reformasi selama periode 1998-2005, faktor-faktor apa saja yang mempengaruhi dan bagaimana hal itu berlangsung. Etnik apa saja yang terlibat dalam konflik tersebut dan bagaimana penyelesaiannya serta dampak yang ditimbulkan dari terjadinya konflik tersebut?

\section{Etnisitas Masyarakat Aceh}

Perselisihan etnik dalam warna identitas sering dikaitkan dengan aspek kesejarahan. Apadurai dalam Baso (2002) mengatakan bahwa sebagai production of nativies, yaitu produksi "pribumi"(Baso, 2002: 41). Seiring dengan hal tersebut maka Fiscer (1986), menegaskan bahwa etnisitas pada dasarnya merupakan sesuatu yang dalam setiap generasi harus ditemukan kembali (reinvented) dan diinterpresentasikan kembali (reinterpreted) oleh setiap individu dan bukan sesuatu yang sederhana yang diwariskan dari generasi ke generasi dan perlu dilestarikan (Kambo, 2007: 45).

Dari kajian Denys Lombard (2008) dapat diketahui bahwa pada abad XVII nama 'Aceh' lebih tepat disebut 'Aceh Dar us-Salam (artinya “Tanah Damai”). Pada saat itu Aceh masih berwujud kota itu sendiri yang kemudian diperluas, sampai seluruh pulau dinamakan dengan sebutan yang sama sebagaimana tercermin pada ungkapan berikut "Semua orang yang berada di Hindia dan di tempat-tempat lain di balik Tanjung Harapan, pergi ke Achen (maksudnya Aceh), sebab dalam kota dan pelabuhan itu terkandung nama dan keagungan seluruh pulau, seperti halnya dengan Banten di Jawa Besar" (Lombard, 2008: 29).

Dengan demikian, merujuk pada pandangan Barth (1998), bahwa yang dimaksudkan etnik Aceh adalah (1) masyarakat yang berkembang biak dan bertahan di wilayah Aceh; (2) mempunyai nilai-nilai budaya yang sama yaitu budaya Aceh pada umumnya dan sadar akan kebersamaannya dalam budaya tersebut serta dalam satu bentuk budaya, yakni budaya yang mereka istilahkan dengan budaya Aceh; (3) membentuk jaringan komunikasi dengan bahasa ibu atau bahasa lokal yang mereka namakan bahasa Aceh, dan berinteraksi dengan lingkungan etnik sendiri (suku Aceh), dan ; (4) menentukan ciri kelompoknya sendiri, seperti bentuk fisik yang diterima oleh kelompok lain sebagai etnis Aceh yang berbeda dengan etnis lainnya seperti etnis Jawa, etnis Batak, etnis Minang, etnis 
Melayu dan dapat dibedakan dari kelompok komunitas yang lain dalam arti tingkah laku dan perlakuannya. Dalam buku Tamaddun Aceh disebutkan bahwa yang termasuk etnis Aceh terdapat enam kelompok yaitu Gayo, Aceh, Tamiang, Jamik, Gayo Alas, dan Simelue.

Berdasarkan uraian di atas dapat dikemukakan bahwa yang dimaksudkan etnis Aceh adalah secara universal mereka berkembang biak dan bertahan pada wilayah atau daerah yang disebut daratan Aceh. Melaksanakan nilai-nilai budaya dan adat yang mereka percayai dan yakini bahwa bahwa hal tersebut merupakan budaya warisan dari indatu (nenek moyang mereka). Mereka selalu berinteraksi dan berbaur dengan kelompoknya dan terikat dengan keluarga besarnya (extended of family) dengan bahasa yang saling mengerti dan khusus (dalam arti hanya kelompoknya) yang memahami bahasa tersebut yakni dengan bahasa Aceh. Disamping itu, mereka mempunyai ciri-ciri anatomi dari fisik (tenotifik) yang berbeda dengan etnis lain yang berada di sekeliling mereka, seperti etnis Melayu, etnis Gayo, etnis Karo, Batak atau etnis pendatang dari luar Sumatra seperti etnis Jawa. Dalam melihat bentuk aneka warna suatu bangsa Ilmu Antropologi yang berkaitan dengan Ilmu Anatomi akan menjawab bentuk aneka warna manusia berdasarkan garis keturunan dan golongan darah.

\section{Asal Usul Etnisitas di Aceh}

Dari beberapa sumber belum ditemukan dengan pasti kapan mulai penyebaran etnis Aceh serta asal-usul yang sebenarnya. Namun ada cerita dari mulut ke mulut bahwa asal nama Aceh adalah dari singkatan bangsa-bangsa yang terdiri dari 4 huruf dan 4 bangsa. Pertama A yang dimaksud singkatan dari kata Arab yang berarti bangsa Arab. Memang pada kenyataannya bahwa ada sebagian etnis Aceh yang merupakan keturunan dari bangsa Arab. Seperti tampak dari gelar bangsawan Said atau Habib (untuk sebutan di Jawa) atau dari bentuk fisik dan dari segi kepercayaan serta aktivitas dagang dari turunan Arab. Masalah kepercayaan dan banyak para turunan Arab mendirikan pesantern atau dayah seperti di pasantren Seulimem, bahwa tengku (ustad) yang membuka pesantren tersebut adalah keturunan Arab (ACEHBala Cossa.com). Kedua C (Tj) adalah singkatan dari kata Cina (Tjina), artinya bahwa ada sebagian dari etnis Aceh merupakan keturunan dari bangsa Cina dan ahli di bidang perdagangan dan pandai membuat mie, yang merupakan ciri khas makanan orang Cina. Ketiga huruf E adalah singkatan dari kata Eropa, artinya ada sebagian orang Aceh yang mirip dengan turunan bangsa Eropa. Hal ini bisa diamati dari bentuk fisik berupa mata biru, hidung mancung dan kulit putih, yakni orang-orang yang tinggal di daerah Lamno Aceh Barat. Orang Aceh juga memiliki hobby yang sama seperti orang-orang Eropa yang gemar berperang. Keempat, huruf $\mathrm{H}$ adalah singkatan dari kata Hindia/India, artinya ada sebagian orang Aceh yang merupakan keturunan India. Hal ini bisa kita buktikan dari segi makanan roti cane, masakan kare dan gemar memakan sirih yang digemari orang India, juga digemari orangorang Aceh. Bentuk fisik tinggi besar namun warna kulit hitam seperti orang Srilangka. Orang-orang ini bisa dijumpai pada masyarakat di daerah Pidie. 
Sudirman (2009) mengemukakan, bahwa semenjak jaman neolitikum, selat Malaka merupakan terusan penting dalam gerak migrasi sebagai jalan niaga dunia serta jalan penghubung utama dua kebudayaan besar, Cina dan India. Muncul dan berkembangnya negara-negara sekitar selat Malaka tidak dapat dipisahkan dari letak geografis yang sangat strategis. Kutaraja (Banda Aceh) muncul sebagai pusat politik dan pemerintahan disebutkan diantaranya oleh karena faktor letak tersebut (Sudirman, 2009: 7). Burger (1962) dalam "Sejarah Ekonomi Sosiologis Indonesia, mengemukakan, bahwa Aceh sudah dikenal semenjak permulaan terbentuknya jaringan-jaringan lalu-lintas internasional sejak abad I masehi (Burger, 1962: 14). Adapun penyebaran etnis Aceh sudah tersebar ke seluruh daratan wilayah Aceh sejak wilayah ini ada, mulai pantai bagian timur yang berbatasan dengan wilayah Sumatra Utara terus membentang ke pantai barat, kemudian di pedalaman dan pegunungan serta di dataran tinggi Gayo.

Pada awalnya sekitar abad VII, bahwa etnik Aceh masih mempunyai kepercayaan Hindu, hal ini bisa dibuktikan dengan hadirnya dua kerajaan Hindu Indrapuri dan Indrapurba (Lamuri) di kawasan Aceh Besar, dan diyakini bahwa kerajaan Lamuri merupakan cikal bakal Kerajaan Aceh Darussalam yang kemudian berkembang menjadi kerajaan Islam setelah kedatangan pedagang-pedagang Islam yang diterima dan bekerjasama dengan penguasa-penguasa lokal.

\section{Penyebaran Etnis dan Potensi Konflik Aceh}

Penyebaran etnis Aceh di wilayahnya tidak terlepas dari perkembangan penduduk Aceh saat itu. Sudirman (2009) menyampaikan perkembangan penduduk Aceh dimulai pada tahun 1570-an, yakni pada kegiatan ekonomi dan militer yang melibatkan sekitar 80.000 penduduk. Anthony Ried menambahkan bahwa sekitar tahun 1570-1580 M, Banda Aceh merupakan sebuah kota pelabuhan yany berciri khas Melayu. Lahan pemukiman begitu luas, tetapi hanya pusat perdagangan dan politik saja yang berpenduduk padat, sekitar 20.000 orang penduduk per $\mathrm{km}$. Dari hal itu dapat diketahui perkembangan penduduk cukup padat pada wilayah yang menjadi pusat kegiatan ekonomi dan perdagangan. Sementara itu, daerah-daerah Aceh yang lain terutama di bagian Pantai Timur, hanya wilayah Perlak yang mampu menompang perekonomian penduduk dari hasil jasa dan perdagangan. Namun kapan pastinya penyebaran penduduk ke wilayah pantai timur itu dimulai, belum ditemukan data yang pasti.

Dalam kajian konflik Aceh khususnya di wilayah Pantai timur Aceh (Aceh Timur, Langsa dan sekitarnya), penulis mengunakan pendekatan sosiologi sejarah agar dapat diketahui proses-proses dan persoalan structural yang membingkai terjadinya konflik tersebut(Ank ersmit, 1987: 267). W.J. Cahnmann dan A. Boskoff, menegaskan bahwa dengan pendekatan sosiologi sejarah, dapat ditemukan pola interaksi antar komunitas yang diwujudkan suatu pola jaringan masyarakat, bagimana itu dilembagakan dan mengalami perubahan. Komunitas yang terdiri dari individu tidak dilihat sebagai pencipta, melainkan sebagai hasil daya-daya masyarakat. Sejalan dengan pandangan tersebut pernah dikemukakan oleh Donald 
Macrae bahwa "sociology is history with the hard work left out", sedangkan "history is sociology with the brains left out". Demikian juga Leopold von Ranke dalam Kuntowijoyo (2008: 267) mengeluarkan dictum bahwa sejarawan hendaknya menulis wie es eigentlich gewesen (yang sebenarnya terjadi). Artinya, sejarawan harus tunduk kepada fakta, sejarawan harus mempunyai integritas, dan sejarawan harus objektif (imparsial, tak boleh memihak).

Konflik Aceh terjadi dalam waktu yang sangat panjang, yakni jauh sebelum Indonesia didirikan hingga Indonesia kontemporer dan merebak lagi pasca reformasi tahun 1998 sampai tahun 2005. Konflik pada periode ini cukup menarik karena beberapa hal antara lain; (1) dalam konflik Aceh ini berpengaruh dalam struktur sosial masyarakat (2) konflik yang terjadi sarat dengan kepentingan para elite di Aceh, yang meyeret dalam konflik antar etnik (konflik horisontal) (3) objek konflik adalah entik pendatang khususnya etnik Jawa yang direpresentasikan sebagai perpanjangan tangan pemerintah pusat. Konflik Aceh tempo dulu hingga era orde baru tidak pernah melibatkan posisi etnik (Jawa). Posisi etnik Jawa pada waktu itu bukan sebagai objek dari konflik itu sendiri. Namun posisi itu berbeda dalam konflik tahun 1998, etnik Jawa justru yang menjadi objek dalam konflik tersebut. Posisi yang sangat terjepit bahwa seolah-olah etnik Jawa menjadi kambing hitam dalam menghalalkan sebuah tindakan dan dalam urusan politik. Dalam kasus ini, penting diungkap kausalitas dalam hubungan antaretnik.

Hubungan antaretnik di Aceh sudah berlangsung sejak lama bahkan sepanjang perjalanan sejarah Aceh itu sendiri. Sebagai bukti adanya beberapa gamponggampong (artinya wilayah kelurahan) yang berisi para saudagar baik dari wilayah Nusantara sendiri dan wilayah di luar Nusantara. Terdapat nama kampong Jawa, kampong Cina, kampong Kedah, kampong Melayu, yang hingga dewasa ini masih tetap eksis di Kutaraja Banda Aceh. Hal ini tentu merupakan bukti kuat bagaimana hubungan dan ikatan persaudaraan antar etnik selama ini tidak pernah luntur. Khusus Aceh dan Jawa, juga memiliki akar sejarah yang Panjang. Pada saat pasukan Jawa (Demak) mengusir Portugis dari Malaka (1521), pasukan Demak mendapat bantuan dari pasukan Pase (Aceh), dan dari ikatan tersebut adanya niat seorang bangsawan dari Pase yang ikut hijrah ke Jawa (Demak) yang akhirnya dipersuntingkan putri Sultan Demak dengan salah satu bangsawan dari Pase tersebut, dan akhirnya diberi tugas sultan Demak dalam rangka menghalau Portuhgis di Batavia dan misi penyebaran Islam di Jawa Barat.

\section{Struktur Masyarakat Majemuk Terdistorsi}

Sebagaimana struktur masyarakat Indonesia, Aceh juga memiliki struktur masyarakat yang majemuk atau plural. Pluralitas masyarakat ini merupakan fakta sejarah yang menjadi modal dasar bagi terciptanya integrasi, tetapi pada sisi yang lain juga dapat menjadi ancaman terjadinya segregasi bahkan disintegrasi. Sebagaimana yang dikemukakan oleh van den Berghe bahwa: (1) terjadi segmentasi ke dalam bentuk kelompok-kelompok yang seringkali memiliki kebudayaan, atau lebih tepat sub-kebudayaan, yang berbeda satu satu sama lain (2) memiliki struktur 
sosial yang terbagi-bagi ke dalam lembaga-lembaga yang bersifat non komplementer (3) kurang mengembangkan konsensus di antara para anggota masyarakat tentang nilai-nilai sosial yang bersifat dasar (4) secara relatif sering terjadi konflik diantara kelompok yang satu dengan kelompok yang lainnya (5) secara relatif integrasi sosial tumbuh di atas paksaan (coercion) dan saling ketergantungan di dalam bidang ekonomi, serta (6) adanya dominasi politik oleh suatu kelompok atas kelompokkelompok yang lain.

Parsons (1951) menyatakan bahwa sistem budaya dan sistem kepribadian dianggap bersinggungan langsung dengan sistem sosial sehingga pengaruh sistem tersebut dapat dibagi hanya dalam konseptualtualisasi subjektif. Parsons melihat integrasi sebagai fungsi utama dalam sistem sosial. Secara spesifik, Parsons mengkonseptualisasi suatu masyarakat tipe ideal yang di dalamnya nilai-nilai budaya diinstitusionalisasikan dalam sistem sosial dan norma-norma diinternalisasikan ke dalam sistem kepribadian. Lalu, dengan demikian menurut pandangan ini bahwa individu akan menuruti ekspektasi-ekspektasi sosial, karena mereka menganggap peraturan itu sah (menginggat sumbernya) dan karena peraturan itu konskuen dengan nilai-nilai mereka yang diinternalisasikan itu. Selain itu, karena dihasilkan dari orientasi nilai bersama, norma mempunyai satu "karakter selaras", sehingga ekspektasi-ekspektasi yang saling bersaing tidak menjerumuskan orang ke dalam konflik.

\section{Konflik Aceh dalam Pandangan Teori Parsons}

Konflik sebagai manifestasi dari adanya suatu kondisi yang bertentangan atau ketidakselarasan/disharmoni dapat dijelaskan dengan teori structural fungsional Talcott Parsons dalam bingkai skema Adaptation, Goal Atainment, Integration, Latency (AGIL). Suatu harmoni terbangun manakala tindakan social masyarakat sebagai sistem social memeninuhi empat kriteria dalam AGIL tersebut. Dalam karya berikutnya yang berjudul The Social System, Parson melihat aktor sebagai orientasi pada situasi dalam istilah motivasi dan nilai-nilai. Terdapat berberapa macam motivasi, antara lain kognitif, chatectic, dan evaluative. Terdapat juga nilai-nilai yang bertanggungjawab terhadap sistem sosial ini, antara lain nilai kognisi, apresiasi, dan moral. Parsons sendiri menyebutnya sebagai modes of orientation. Unit tindakan oleh karenanya melibatkan motivasi dan orientasi nilai dan memiliki tujuan umum sebagai konsekuensi kombinasi dari nilai dan motivasi-motivasi tersebut terhadap seorang aktor.

Sementara itu, Merton (murid Talcott Parsons) mengembangkan lebih lanjut teori structural fungsional dengan mengawali kritikan terhadap beberapa aspek ekstrem dan keteguhan structural fungsionalisme sebagai basis membangun harmoni sosial dan dalam konteks ini Merton mendorong fungsionalisme kearah marxisme. Hal ini berbeda dari sang guru, Talcott Parsons mengemukakan bahwa teorisi structural fungsional sangatlah penting. Parsons mendukung terciptanya teori yang besar dan mencakup seluruhnya sedangkan Merton lebih terbatas dan menengah, tetapi lebih operasional dan kontekstual. Merton mengkritik apa yang 
dilihatnya sebagai tiga postulat dasar analisis fungsional, seperti yang pernah dikembangkan oleh Malinowski dan Radcliffe Brown.

Beberapa postulat yang dikritisi Merton tersebut antara lain: (1) kesatuan fungsi masyarakat, seluruh kepercayaan dan praktik sosial budaya standar bersifat fungsional bagi masyarakat secara keseluruhan maupun bagi individu dalam masyarakat, hal ini berarti sistem sosial yang ada pasti menunjukan tingginya level integrasi. Hal yang demikian tidak hanya berlaku pada masyarakat kecil tetapi dapat generalisasikan pada masyarakat yang lebih besar (2) fungsionalisme universal, seluruh bentuk dan stuktur sosial memiliki fungsi positif. Hal ini di tentang oleh Merton, bahwa dalam dunia nyata tidak seluruh struktur, adat istiadat, gagasan dan keyakinan, serta sebagainya memiliki fungsi positif. Dicontohkan pula dengan stuktur sosial dengan adat istiadat yang mengatur individu bertingkah laku kadangkadang membuat individu tersebut depresi hingga bunuh diri. Dengan demikian postulat structural fungsional menjadi bertentangan (3) indispensability, aspek standar masyarakat tidak hanya memiliki fungsi positif, namun juga merespresentasikan bagian-bagian yang tidak terpisahkan dari keseluruhan yang adakalanya negatif. Hal ini berarti fungsi secara fungsional diperlukan oleh masyarakat. Dalam hal ini Merton sama dengan Parsons bahwa ada berbagai alternative structural dan fungsional yang ada di dalam masyarakat yang tidak dapat dihindari.

Dalam bagian terakhirnya Parsons (1951), berasumsi bahwa setiap subsistem normalnya memiliki sarana untuk perubahan, dan sebagian besar dalam tulisannya menganggap perubahan itu menyusahkan karena bisa membahayakan imperatifimperatif sistem. Lebih lanjut, Parsons khawatir bahwa akibat dari perubahan yang tampaknya remeh boleh jadi jangkauannya luas (dan lebih buruk) daripada yang mungkin diperhitungkan orang. Analisis perubahan yang secara eksplisif itu dilakukan dalam perspektif evolusioner yang tertib. Jadi masyarakat digambarkan bergerak melewati tahap-tahap equilibrium temporer, tetapi perubahan yang berlangsung mengikuti suatu urutan yang tertib dan selalu dipolakan sesuai dengan kebutuhan- kebutuhan sistem tersebut.

Sejalan dengan pemikiran Parsons dan Merton tersebut, konflik Aceh dapat dipahami sebagai bagian dari proses bagi terjadinya perubahan masyarakat yang berlangsung equilibrium. Perubahan tersebut dilakukan boleh jadi secara sengaja, maka terjadi hubungan kausalitas dengan dinamika dan konflik di masyarakat. Pertama, adanya kecenderungan pola-pola tradisional yang berfungsi pada pemerintahan Provinsi Aceh. Melalui Perjanjian dalam MoU Helsinki tanggal 15 Agustus 2005, menstimulan lahirnya Undang Undang Negara RI No.11 Th. 2006 tentang Undang Undang Pemerintahan Aceh (UUPA). Di dalam undang-undang tersebut telah disebutkan tentang lembaga-lembaga adat yang mempunyai fungsi dalam struktur pemerintahan Aceh. Kedua, melibatkan tendensi untuk tidak mempertimbangkan kemungkinan bahwa praktek-praktek tradisional memberi manfaat secara berbeda kepada beberapa bagian dalam suatu masyarakat. Dalam bagian ini tampak praktek-praktek tradisional suatu daerah sangatlah berbeda 
dengan daerah lain. Maksudnya bahwa peraturan-peraturan adat terakomodir menjadi peraturan yang tertulis yang menjadi ketetapan adat yang harus dijalankan bagi seluruh warga Aceh. Meskipun dalam kenyataannya masih adanya ketimpangan dalam menjalankan syariat Islam dan masih adanya pro dan kontra. Ketiga, yang menompang kekonservatifan fungsionalisme struktural. Parsonsian menunjukkan adanya keengganan untuk memberikan tempat utama bagi kajiannya atas isu tentang konflik, pertentangan, atau kekerasan. Sejalan dengan pemikiran Parsonian, dalam struktur masyarakat tradisional Aceh, selalu berpandangan bahwa konflik adalah suatu hal yang tabu yang tidak baik untuk dilakukan, walaupun faktualnya konflik belum tentu mempunyai dampak yang negatif. Akan tetapi dalam kenyataan bahwa konflik Aceh yang sangat keras bahkan adakalanya berdarah itu terselesaikan secara damai dan pasca konflik masyarakat merasakan lebih tenang serta muncul pembangunan di segala bidang. Hal itu tentu tidak terlepas dari mulai berjalannya system social yang menekankan pada proses AGIL sebagaimana pemikiran yang dikembangkan oleh Parsonian.

Selain itu, dikarenakan subsistem-subsistem itu saling bersinggungan, Parsons dalam teorinya tidak harus saling memaksa satu sama lain untuk menuruti ekspektasi-ekspektasi yang logis, mereka ingin untuk patuh. Menurut pandangan Gouldner (1970), bahkan tendensi sebagian besar fungsional tidak memberikan banyak ruang terhadap analisis konflik dan hal itu sekaligus menjadi bukti dari adanya keengganan mereka untuk melihat konflik. Adapun ketiga pandangan Parsons tersebut antara lain: (1) preferensi kepada inferensi-inferensi orang luar, karena Parsons berpendapat bahwa individu menginternalisasi nilai-nilai inti yang sama, refleksi mereka mungkin memberikan indikator-indikator sosial yang sah, (2) perbedaan antara individu dan kolektivitas. Parsons tentu saja menegaskan pemisahan antara individu dan kolektivitas, dan tidak dapat direduksinya lagi sistem sosial, dan dia pun memandang sistem sosial bersinggungan atau merembesi sistem kepribadian, (3) integrasi sosial, tanpa 'campur tangan' menjadi ide utama dalam skema Parsons. Menurut pandangannya, bagian yang sesuai, dan setelah tercapai equilibrium, kelanjutannya tidak memerlukan syarat mekanisme khusus apapun, karena kondisi equilibrium dalam system social sendiri menjadi penciri pemikiran Parsons.

Dalam orientasi umum Parsons (1966) untuk studi tentang perubahan sosial dibentuk oleh factor yang bersifat biologi. Untuk menerangkan proses ini Parsons mengembangkan apa yang disebut "Paradigma Perubahan Evolusioner". Komponen pertama dalam paradigma itu adalah proses diferensiasi. Parsons berasumsi bahwa setiap masyarakat tersusun dari sekumpulan subsistem yang berbeda berdasarkan struktur maupun berdasarkan makna fungsionalnya bagi masyarakat yang lebih luas. Ketika masyarakat berubah, subsistem baru terdiferensiasi. Akan tetapi hal ini belum lah cukup, subsistem baru ini juga harus lebih mempunyai kemampuan dalam menyesuaikan diri ketimbang subsistem yang terdahulu. Jadi, aspek esensial paradigma evolusioner Parsons adalah kemampuan menyesuaikan diri yang meningkat (Parsons, 1966: 222, Ritzer, 2011:133). 
Dalam kasus di Aceh, perubahan ini disebabkan oleh terjadinya konflik, atau perubahan yang dipaksakan. Perubahan ini terjadi karena adanya gejolak masyarakat, baik masyarakat pendatang maupun lokal. Gejolak masyarakat pendatang, mereka merasa bahwa dirinya juga sudah tinggal lama dan menetap tinggal di Aceh, bahkan ada yang sudah lebih dari dua gerenasi. Bagaimanapun juga mereka akan mempertahankan tempat tinggalnya, bagi warga yang tidak suka akan keributan, mereka akan memilih pergi, merantau ke luar Aceh dengan pilihan daerah yang masih alamiah seperti Pekanbaru atau pulang ke daerah asal Pulau Jawa bagi yang masih mempunyai ikatan saudara di Jawa. Pada sisi lain, terjadi keterikatan sosial, rasa penderitaan, rasa memiliki dan rasa ingin mempertahankan bersama dalam bingkai ke-etnikan. Ketika terjadi gejolak dan gesekan dengan etnik Aceh, maka mereka akan terintegrasi dengan masyarakat yang sama dalam bingkai etnik yang sama.

Konflik ideologis memang lebih mudah disimak dalam kasus-kasus hubungan dan perbedaan-perbedaan agama. Akan tetapi karena perbedaan agama yang seringkali bertemu juga dengan perbedaan suku bangsa, maka konflik yang demikian sedikit banyak terdapat juga di antara suku-suku bangsa yang lain. Apalagi jika diingat bahwa perbedaan tradisi adat bukan sedikit terjadi di antara berbagai suku bangsa, dalam keadaan konflik yang terbuka benar-benar terjadi, maka sentimen keagamaan seringkali bertemu dengan sentimen kesukuan. Konflik ideologis bisa terjadi juga pada kasus konflik antaretnik di Kalimantan, Papua, Poso, tetapi untuk kasus konflik di Aceh tidak menutup kemungkinan konflik ideologis juga konflik politis. Nasikun (1984), mengemukakan perbedaan yang sangat mendasar diantara berbagai kelompok di masyarakat, seperti masalah yang berkaitan dengan nilai-nilai dasar (Nasikun, 1984: 88-98).

Bagian akhir dari proses konflik untuk mewujudkan harmoni social adalah integrasi. Suatu sistem sosial yang senantiasa mengintegrasi di atas landasan dua hal berikut. Pertama, suatu masyarakat senantiasa terintegrasi di atas tumbuhnya konsensus di antara sebagaian besar anggota masyarakat akan nilai-nalai kemasyarakat yang bersifat fundamental. Kedua, suatu masyarakat yang senatiasa terintegrasi juga oleh karena berbagi anggota masyarakat sekaligus menjadi anggota berbagai kesatuan sosial (cross cutting affiliations). Dengan demikian setiap konflik yang terjadi di antara suatu kesatuan sosial yang lain segera akan dinetralisir oleh adanya loyalitas ganda (cros cutting loyalities) dari para anggota masyarakat terhadap berbagai kesatuan sosial yang ada.

Pada tingkat tertentu keduanya akan mendasari terjadinya integrasi sosial di dalam masyarakat yang bersifat majemuk, oleh karena tanpa keduanya suatu masyarakat bagaimana pun tidak mungkin terjadi. Akan tetapi sifat-sifat masyarakat majemuk sebagaimana yang telah disebutkan di atas, telah menyebabkan landasan terjadinya integrasi sosial seperti yang dikemukakan oleh para penganut fungsionalisme struktural hanya dapat berlaku di dalam derajat yang terbatas. Segmentasi dalam bentuk terjadinya kesatuan-kesatuan sosial yang terikat ke dalam ikatan-ikatan primodial dengan sub-kebudayaan yang berbeda satu sama lain, akan 
mudah sekali menumbulkan konflik di antara kesatuan-kesatuan sosial tersebut, seperti kasus baik di Aceh, Kalimantan dan Irian Barat (Papua). Oleh karena itu ada dua macam tingkatan konflik yang mungkin terjadi, yakni: (1) konflik di dalam tingkatnya yang bersifat ideologis, dan (2) konflik di dalam tingkatnya yang bersifat politis.

Pada tingkatnya yang bersifat ideologis, konflik tersebut terwujud di dalam bentuk konflik antara sistem nilai yang dianut dan menjadi ideologi dari berbagai kesatuan sosial. Adapun pada tingkatan yang bersifat politis, konflik tersebut terjadi di dalam bentuk pertentangan di dalam pembagian status kekuasaan, dan sumbersumber ekonomi yang terbatas adanya di dalam masyarakat. Di dalam situasi konflik, maka sadar atau tidak sadar bahwa setiap pihak yang berselisih akan berusaha mengabadikan diri dengan cara perlakuan memperkokoh solidaritas ke dalam di antara sesama anggotanya, membentuk organisasai-organisasi kemasyarakatan untuk keperluan kesehjahteraan dan pertahanan bersama, seperti memperkuat identitas kultural.

\section{Penutup}

Dari pembahasan yang telah dilakukan tersebut, maka dapat dibuat simpulan bahwa konflik pada dasarnya inheren dalam kehidupan masyarakat apalagi pada masyarakat yang majemuk atau pluralistic potensi konflik yang berlatar etnik dapat dikatakan selalu ada menyertai. Kasus konflik di Aceh terutama pada masa reformasi 1998-2005 menjadi bukti otentik terjadinya konflik yang berlatar etniksitas khususnya antara etnik lokal dengan etnik pendatang yang dalam hal ini adalah etnik Jawa. Dengan demikian, konflik selalu menjadi sesuatu yang potensial di dalam masyarakat yang bersifat majemuk, dan apabila konsensus hanya dapat tumbuh dalam derajat yang terbatas, maka bagaimana mungkin suatu masyarakat majemuk dapat bertahan dalam waktu yang panjang. Disamping itu, suatu masyarakat majemuk dapat juga terintegrasi oleh karena adanya saling ketergantungan dan saling membutuhkan di antara berbagai kelompok atau kesatuan baik dibidang sosial tersebut maupun di dalam lapangan ekonomi.

Konflik etnisitas di Aceh pada masa reformasi dalam pandangan teori structural fungsional dapat dipahami sebagai media untuk membangun dan memperkuat kohesi sosial bahkan integrasi social ketika system social dalam masyarakat fungsional dalam formasi equilibrium. Hal ini dibuktikan dari adanya respon dan tindaklanjut dari unsur-unsur social potensial masyarakat untuk melakukan komunikasi dan tindakan-tindakan yang menunjukkan adanya proses adaptasi, penyelarasan tujuan bersama dan penyatuan serta integrasi sebagai komunitas yang tinggal dikawasan tempat tinggal yang sama, yaitu Aceh. Bukti otentik yang bersifat legal formal adalah proses-proses social dan politik yang menyertai dan menghasilkan kesepakatan dalam MoU Helsinki tanggal 15 Agustus 2005 di mana masyarakat Aceh menjadi memiliki media untuk melakukan proses adaptasi social hingga integrasi sosial dalam kehidupan masyarakat Aceh yang secara factual majemuk. Bertitik tolak dari hal itu, maka konflik Aceh dapat menjadi 
jembatan untuk menuju pada terjadinya perubahan masyarakat sebagaimana yang dipikirkan pengikut fungsionalis struktural di mana perubahan sosial akan terjadi pada masyarakat majemuk, tetapi perubahan yang secara evolusi, atau perubahan yang secara alami. Masyarakat akan mengalami perubahan dari masyarakat yang kurang baik menjadi masyarakat yang tertata dengan baik, teratur dan damai. Artinya perubahan yang dikehendaki tetapi tidak dipaksakan dan cenderung berlangsung dalam kondisi damai.

\section{References}

Baso, Ahmad (2002). Plesetan Lokalitas Politik Pribumi Islam. Jakarta: Desantara.

Barth, Fredrik (1988). Kelompok Etnis dan Batasannya. Jakarta: Universitas Indonesia Press.

Burger, D.H. (1962). Sejarah Ekonomi Sosiologis Indonesia Jilid I. Jakarta: Pradnja Paramita.

Burger, P.L., Parera, F. M. and Luckman (1990). Tafsir Sosial Atas Kenyataan Risalah tentang Sosiologi Pengetahuan. Jakarta: LP3ES.

Eriksen, Thomas H. (1993). Ethnicity E Nationalism, Anthopological Perspectives. London: Pluto Press.

Haryanto, Sindung (2012) "Konflik Sosial di Era Reformasi", Masyarakat, Kebudayaan dan Politik, Vol. 25 (4): 299-308.

Herowitz, Donald (1985). Ethnic Group in Conflict. Los Angeles: University Of California Press.

Kambo, Gustiana (2007). Politik Identitas: Studi Kualitatif Tentang Konstruksi Identitas Politik Etnik Mandar. Disertasi Universitas Airlangga.

Kuntowijoyo (2008). Penjelasan Sejarah [Historical Explanation]. Yogyakarta: Tiara Wacana.

Lombard, Denys (2008). Kerajaan Aceh Zaman Sultan Iskandar Muda (1607-1636). Jakarta: KPG.

Manger, Martin (1994). Elite and Masses. California, Wadsworth Publishing Company: Belmort.

Nasikun (1984). Sistem Sosial Indonesia. Yogyakarta: Universitas Gadjah Mada Press.

Parsons (1951) Social System. Oxon: Routledge \& Kegal Paul Ltd.

Parsons (1966) Societies: Evolutionary and Comparative Perspectives. New Jersey: Prentice-Hall.

Reid, Anthony (2004) "War, Peace, and the Burdern of History in Aceh", Asian Ethnicity, Vol. 5 (3): 301-314.

Reid, Anthony (2007). Asal Mula Konflik Aceh-Dari Perebutan Pantai Timur Sumatra hingga Akhir Kerajaan Aceh abad XIX. Jakarta: Yayasan Obor Indonesia.

Ritzer, Georg (2011). Teori Sosiologi Modern. Jakarta: Kencana Prenada Media Group.

Sudirman (2009). Banda Aceh dalam Siklus Perdagangan Internasional 1500-1873, Banda Aceh: Balai Pelestarian Sejarah dan Nilai Tradisional. 